\title{
Use of Zebrafish (Danio rerio) Embryos as a Model to Assess Effects of Mercury on Developing Skeletal Muscle: A Morphometric and Immunohistochemical Study
}

\author{
Uso de Embriones de Pez Cebra (Danio rerio) Como Modelo para Evaluar los Efectos del Mercurio \\ en el Desarrollo del Músculo Esquelético: Un Estudio Morfométrico e Inmunohistoquímico
}

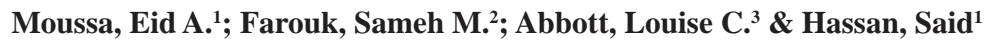

MOUSSA, E. A.; FAROUK, S. M.; ABBOTT, L. C. \& HASSAN, S. Use of zebrafish (Danio rerio) embryos as a model to assess effects of mercury on developing skeletal muscle: a morphometric and immunohistochemical study. Int. Morphol., 36(3):901-908, 2018.

SUMMARY: Exposure to mercury in the environment continues to be a significant worldwide concern, especially for developing embryos and fetuses. While extensive research effort has focused on the effects of mercury on the developing nervous system, much less is known concerning adverse effects of mercury on other organ systems, including the development of skeletal muscle. We exposed developing zebrafish embryos to a range of concentrations of mercuric chloride (100 to $400 \mu \mathrm{g} / \mathrm{liter}$ or ppb) and compared them to control embryos $(0 \mu \mathrm{g} / \mathrm{L}$ mercuric chloride). Embryos were examined at 48 hours post fertilization (hpf) for morphometry and morphological deformities of skeletal muscle fibers in the trunk and tail. Embryos exposed to $400 \mathrm{ppb}$ mercuric chloride showed decreased trunk and tail areas compared to control embryos. A dose-dependent reduction in muscle fiber length was observed, and exposure to all concentrations of mercuric chloride used in this study resulted in decreased muscle fiber immunohistochemical staining with anti-myosin antibodies. Irregular muscle fiber diameters, twisted muscle fibers, and degenerated muscle fibers were observed in sections of embryos stained with eosin at the higher exposure concentrations. Evidence presented in this study suggests that exposure to even low concentrations of mercuric chloride adversely affects skeletal muscle fiber development or muscle fiber integrity, or both.

KEY WORDS: Zebrafish; Muscle fiber development; Striated muscle; Myosin; Embryonic Development.

\section{INTRODUCTION}

Mercury is a heavy metal contaminant that is found worldwide. Elemental, inorganic and organic forms of mercury are found in our environment, due to geologic activity such as volcanic eruptions, soil erosion, as well as human industrial activity (Liu et al., 2016). Environmental contamination by mercury has increased since the beginning of the industrial revolution, and mercury continues to accumulate in both aquatic and terrestrial systems (Swaddle et al., 2017).

Early embryogenesis is one of the most sensitive life stages to environmental toxicants, and while the developing brain is particularly sensitive to mercury toxicity (Hassan et al., 2012; Chan et al., 2017), other developing organ systems and tissues also are highly susceptible to mercury toxicity. Mechanisms through which mercury affects cellular functions include induction of apoptosis, increased cellular oxidative stress, reduced function of ion channels and neurotransmitter receptors, and perturbations in energy metabolism and calcium balance, primarily through effects on mitochondrial function and integrity are adversely affected when exposed to mercury (Reis et al., 2007; Uchikawa et al., 2016). Mercury also has a pronounced affinity for protein sulfhydryl (SH) groups that, when bound to mercury, will diminish or completely inhibit normal protein function, including enzyme functions (Reis et al.).

Elemental mercury is transformed into methylmercury, an organic form of mercury, by bacteria in water and soil and then methylmercury easily passes through cell membranes to accumulate in plants and small organisms that are eaten by larger organisms such that mercury bioaccumulates in body tissues. Thus, the primary form of mercury to which humans are exposed is methylmercury,

${ }^{1}$ Department of Anatomy and Embryology, Faculty of Veterinary Medicine, Suez Canal University, 41522, Ismailia, Egypt.

${ }^{2}$ Department of Cytology and Histology, Faculty of Veterinary Medicine, Suez Canal University, 41522, Ismailia, Egypt.

${ }^{3}$ Department of Veterinary Integrative Biosciences, College of Veterinary Medicine and Biomedical Sciences, Texas A\&M University, USA. 
primarily through consumption of seafood, but also through eating contaminated rice. Environmentally relevant exposures to mercury have been calculated to be in the range of 1 to $5 \mathrm{ppm}$, and less (Swaddle et al.), but the actual levels of exposure are determined by the degree of contamination and amount of consumption.

While methylmercury tends to accumulate at higher concentrations in brain tissue compared to other tissues in the body, it also accumulates in skeletal muscle (Liu et al.). Once organic forms of mercury, such as methylmercury, are taken inside cells they are typically converted to a demethylated form of mercury (i.e., an inorganic form of mercury) that can reside for long periods of time in cells, since it is much more difficult for inorganic mercury to pass through cell membranes compared to organic forms of mercury (Chan et al.). Exposure to both elemental and inorganic forms of mercury can result in many adverse effects. Severe effects reported in children exposed to non-lethal levels of mercury include developmental delays, limb deformities, physical growth disturbance, blindness, deafness, exaggerated reflexes, and cerebral palsy (Uchikawa et al.).

Because mercury can have a critical impact on protein function, skeletal muscle proteins are particularly susceptible to damage when exposed to even low concentrations of mercury, especially during initial muscle formation (Musiek \& Hanlon, 1999). During embryonic development, skeletal muscle progenitor cells, which are multipotent mesodermal cells, are derived from somites. After a series of cell divisions, most muscle progenitor cells first differentiate into muscle fibers through cell fusion. Continued differentiation occurs through formation, and assembly of the contractile myofibrils and a few progenitor cells remain in fully formed skeletal muscle as a self-renewing population of satellite cells that have important roles in muscle repair following injury (Yin et al., 2013).

Use of zebrafish adults and embryos for toxicity testing provides a number of advantages. Zebrafish are small, inexpensive, easy to maintain and breed, and produce large numbers of embryos. The zebrafish genome is completely sequenced, and their aqueous environment allows direct exposure to toxicants being studied (Scholz et al., 2008). Zebrafish embryos establish a complete body plan by 24 hours post fertilization (hpf), and embryogenesis is finished by $72 \mathrm{hpf}$. Zebrafish embryos are transparent during early development and functioning skeletal muscle fibers are present before $24 \mathrm{hpf}$. An additional advantage to using zebrafish as an animal model is that many morphological and molecular signaling processes that occur during development are either identical or similar to other vertebrates, including man (Scholz et al.).
Gentès et al. (2015) reported that both methylmercury and inorganic mercury exposures to adult zebrafish via their diet $(10 \mu \mathrm{g} / \mathrm{gram})$ resulted in altered gene expression in skeletal muscle, while exposure to methylmercury was specific for morphological changes observed in muscle using electron microscopy. Exposure of adult zebrafish to $244 \mu \mathrm{g} /$ liter of mercuric chloride for seven days resulted in downregulation of acetylcholinesterase and superoxide dismutase in skeletal muscle (Zhen et al., 2014). However, few studies have have reported on the effects of mercury exposure on developing zebrafish skeletal muscle.

Therefore, in this study, we exposed developing zebrafish embryos to a range of low, environmentally relevant, concentrations of inorganic mercury (100 to 400 ppb or $\mu \mathrm{g} /$ liter), in the form of mercuric chloride $\left(\mathrm{H}_{\mathrm{g}} \mathrm{Cl}_{2}\right)$. We hypothesized that exposure to even very low concentrations of mercuric chloride would delay or inhibit skeletal muscle development. We analyzed control and exposed embryos using immunohistochemistry for myosin as well as paraffin-embedded and sectioned embryos stained with eosin. Embryos exposed to all concentrations of mercuric chloride exhibited altered skeletal muscle development.

\section{MATERIAL AND METHOD}

Zebrafish Embryo Production. Adult fish were maintained in the Department of Biology at Texas A\&M University using standard laboratory conditions and a temperature of $28.5^{\circ} \mathrm{C}$ (Westerfield, 2000). Male and female adult zebrafish were paired in the evening, and fertilized embryos were obtained at approximately $10 \mathrm{AM}$ the following morning. Medium to maintain the zebrafish embryos was composed of ultrapure water and low concentrations of specific ions to mimic fresh water and adjusted to $\mathrm{pH} 7.2$ according to Westerfield. Embryo medium was prepared fresh for each experiment. All zebrafish embryos were examined for their stage of development and fixed at specific times after fertilization and recorded as hours post fertilization (hpf) (Westerfield). This study was conducted under an Animal Use Protocol that was approved by the Texas A\&M University Institutional Animal Use Oversight committee. Adult zebrafish were maintained, and embryonic zebrafish were used in experiments according to protocols consistent with the NIH Guide for the Care and Use of Laboratory Animals (Clark et al., 1997).

Mercuric Chloride Preparation and Exposure. Embryos were kept in 24-well flat-bottom plates (BD Biosciences, San Jose, CA, USA). Two ml of embryo medium were added 
to each well. Embryo medium without any mercuric chloride was used as the negative control. For each 24-well plate, four wells were used as positive controls, and contained embryo medium with $2 \%$ ethanol added. The remaining wells were divided equally to contain one of four different concentrations of mercuric chloride (100, 200, 300, $400 \mathrm{ppb}$ ). At six hpf, two to four zebrafish embryos were placed in each well. The 24-well plates were prepared in duplicate, and approximately 96 zebrafish embryos were tested at each concentration of mercuric chloride. The 24-well plates were incubated for $42 \mathrm{~h}$ at $28.5^{\circ} \mathrm{C}$ in a low-temperature laboratory incubator (Thelco; Cole-Palmer Instruments, Vernon Hills, IL, USA). Strict safety precautions concerning protective clothing and gloves were observed relative to personnel working with mercuric chloride solutions in this study. All hazardous liquid and dry waste were collected and properly disposed of by the Texas A\&M University Environmental Health and Safety Office.

Immunohistochemistry. Embryos were anesthetized with MS-222, chilled on ice and then fixed using $10 \%$ neutral buffered formalin for a minimum of $24 \mathrm{~h}$ at $4{ }^{\circ} \mathrm{C}$. Formalinfixed specimens were subsequently stored in $70 \%$ ethanol at $4{ }^{\circ} \mathrm{C}$. Whole-mount immunohistochemical staining of zebrafish embryos was carried out as described previously (Incardona et al., 2004). Anti-myosin heavy chain mouse monoclonal F59 primary antibody was used at a concentration of 1:1000 (Santa Cruz Biotechnology, Inc., Europe) (Li et al., 2014). Embryos at $48 \mathrm{hpf}$ were dechorionated, anesthetized with MS-222, chilled on ice then fixed in $10 \%$ neutral buffered formalin for $24 \mathrm{~h}$, at $4{ }^{\circ} \mathrm{C}$. After fixation, some embryos were processed for whole embryo immunohistochemistry. The fixed embryos were incubated in $0.3 \%$ Triton $x 100$ in phosphate buffered saline, $\mathrm{pH} 7.2$ (PBS) $(1 \mathrm{~h})$, then rinsed in PBS. Then the embryos were incubated in $5 \%$ normal horse serum in PBS (1 h) and placed in anti-myosin antibody at $4{ }^{\circ} \mathrm{C}$, overnight. The next day the embryos were rinsed with PBS and incubated in biotinylated horse anti-mouse secondary antibody (1:400; Vector Laboratories, Burlingame, CA, USA for $2 \mathrm{~h}$ ). Next, the embryos were rinsed in PBS and incubated overnight at $4^{\circ} \mathrm{C}$ in horseradish peroxidase (HRP) bound to Strept-Avidin (1:5000; Kirkegaard \& Perry Laboratories, Inc. Gaithersburg, MD, USA). Following several PBS washes and one final wash with $0.05 \mathrm{M}$ Tris- $\mathrm{HCl}$ buffer ( $\mathrm{pH} 7.6$ ), the tissue-bound peroxidase reaction was visualized using $0.06 \%$ diaminobenzidine (DAB) (Sigma), $0.6 \%$ nickel ammonium sulfate as the chromagen and $0.02 \%$ hydrogen peroxide in $0.05 \mathrm{M}$ Tris- $\mathrm{HCl}$ buffer to initiate the reaction ( $\mathrm{pH} 7.6)$. The $\mathrm{DAB}$ reaction was terminated after $2 \mathrm{~min}$ by transferring the embryos to $0.05 \mathrm{M}$ Tris-HCl buffer ( $\mathrm{pH}$ 7.6). Following termination of the $\mathrm{DAB}$ reaction, the embryos were rinsed in PBS and photographed using an Eclipse E400 microscope equipped with a 2x objective, a DXM1200 digital camera, and ACTI imaging software (Nikon Instruments, Melville, NY, USA). Controls included eliminating the primary antibody from the first exposure step.

Tissue Processing for Paraffin Embedding, Sectioning and Staining. Embryos were anesthetized with MS-222, chilled on ice and then fixed using $10 \%$ neutral buffered formalin for a minimum of $24 \mathrm{~h}$ at $4{ }^{\circ} \mathrm{C}$. Formalin-fixed specimens were subsequently stored in $70 \%$ ethanol at 4 ${ }^{\circ} \mathrm{C}$. For paraffin embedding, the embryos were dehydrated using a graded series of ethanol $(75 \%, 80 \%, 90 \%, 95 \%$ and $100 \%$ ), subjected to three changes of xylene, and then embedded in paraffin. The paraffin-embedded specimens were serially sectioned at a thickness of $5 \mu \mathrm{m}$ and the sections stained with eosin.

Using the eosin-stained sections, we examined developing muscle fibers for evidence of degeneration, which included loss of muscle fibers or loss of fiber organization (Follo et al., 2013). We also observed changes in the myosepta between developing somites. In degeneration of muscle fibers, myosepta appeared narrower. The number of nuclei was altered in degenerating muscle fibers.

Morphometric Measurements. Whole, fixed embryos were photographed using an Eclipse E400 microscope equipped with a 2x objective, a DXM1200 digital camera, and ACT1 imaging software (Nikon Instruments, Melville, NY, USA). The length of the body, the area of the eye, area of the yolk sac area of the tail and trunk were measured for each whole fixed embryo examined.

Statistical Analysis. For assessment of the presence or absence of muscle fiber degeneration, the Chi-square test was used, comparing the exposed embryos to control embryos. One way analysis of variance (ANOVA) was used to determine the significance of observed differences in tail area and muscle fiber length. When we observed a p-value $<0.05$, we ran t-tests that were corrected for multiple comparisons using the Bonferroni correction.

\section{RESULTS}

Beginning at $6 \mathrm{~h}$ post-fertilization, we exposed zebrafish embryos for up to $42 \mathrm{~h}$ to one of five concentrations ( 0 [negative control], 100, 200, 300 and $400 \mathrm{ppb)} \mathrm{mercuric}$ chloride. Embryos were assessed at $48 \mathrm{~h}$ post fertilization for progress in development, morphometry and morphological deformities of skeletal muscles. Regarding whole embryo morphology, we observed a smaller trunk and 


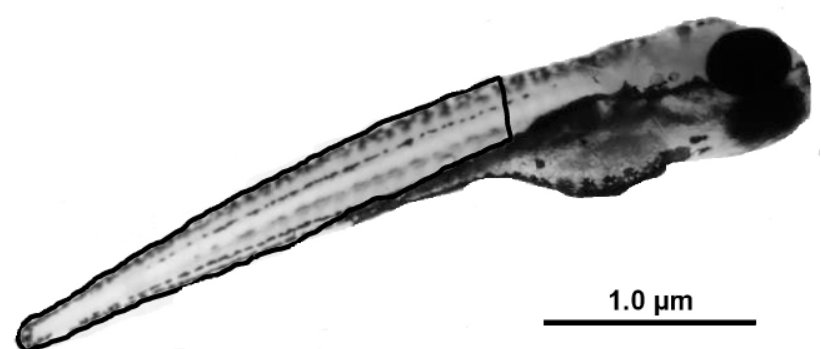

Fig. 1. Photograph of a control, fixed zebrafish embryo. The trunk and tail area are outlined.

tail size in embryos exposed to mercuric chloride, as indicated by measuring the trunk and tail area (Fig. 1). Specifically, embryos exposed to $400 \mathrm{ppb}$ mercuric chloride had a significantly smaller trunk and tail areas compared to control embryos, and embryos exposed to $100 \mathrm{ppb}$ and 200 ppb mercuric chloride (Fig. 2); $p<0.05$ for each comparison, respectively). While there was a trend towards smaller tail areas for embryos exposed to $200 \mathrm{ppb}$ and $300 \mathrm{ppb}$ compared to control embryos, the differences did not achieve statistical significance ( $\mathrm{p}=0.15$ for both comparisons).

When we examined sections from paraffin-embedded zebrafish embryos that were stained with eosin (Fig. 3), we observed decreased muscle fiber lengths in embryos exposed to increasing concentrations of mercuric chloride (Fig. 4). Specifically, embryos exposed to all four concentrations of mercuric chloride had significantly smaller muscle fiber lengths compared to control embryos $(\mathrm{p}<0.001$ for each comparison). A dose-response was observed when muscle fiber lengths were compared between embryos exposed to the different concentrations of mercuric chloride $(\mathrm{p}<0.01$ for all comparisons; Fig. 4).

\section{Effect of $\mathrm{HgCl}$ on trunk and tail area}

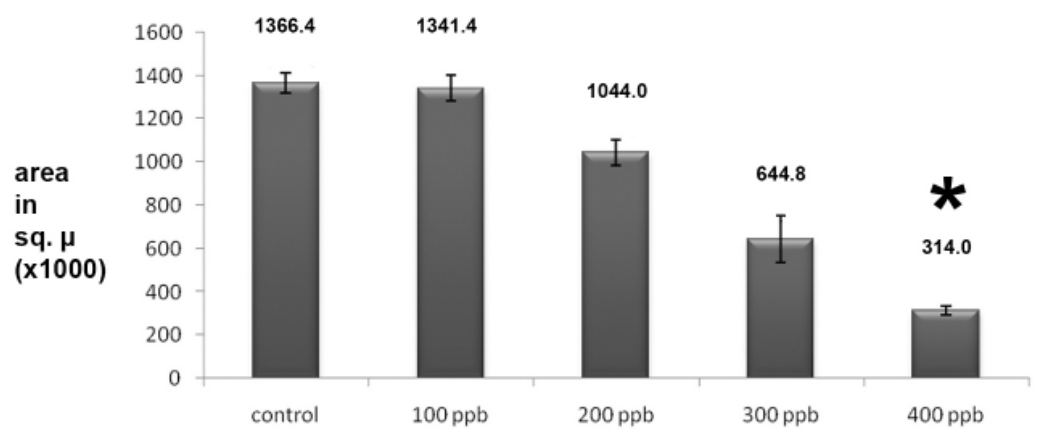

Fig. 2. Graph showing the effect of exposure to different concentrations of mercuric chloride on trunk and tail area. Error bars $=$ SEM; $*=p<0.05$
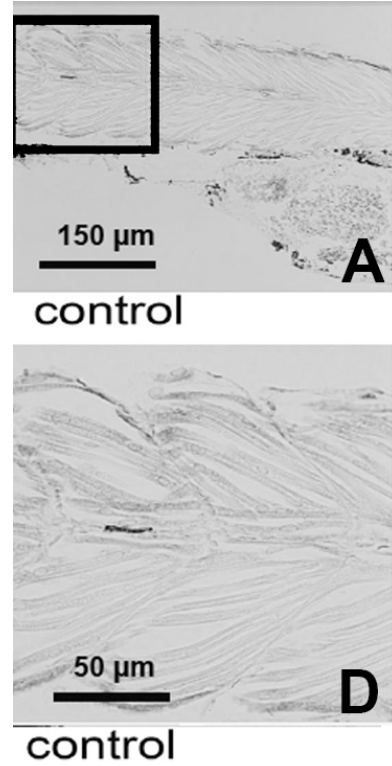

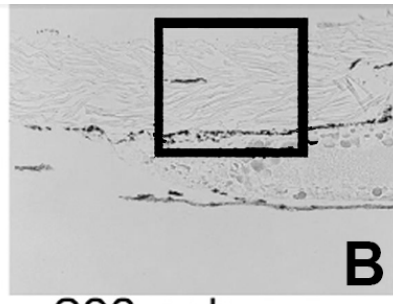

$200 \mathrm{ppb}$

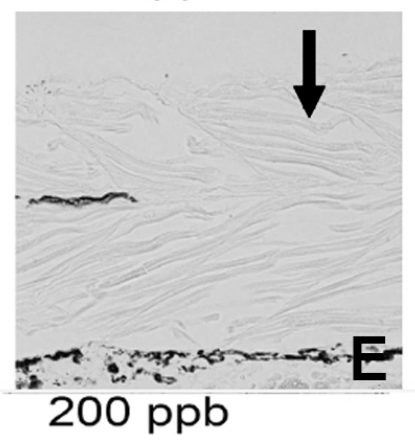

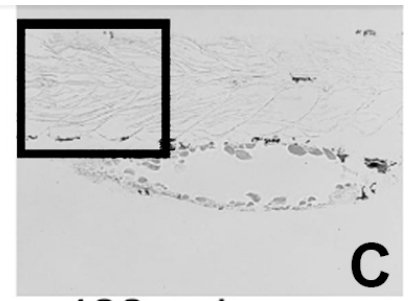

$400 \mathrm{ppb}$

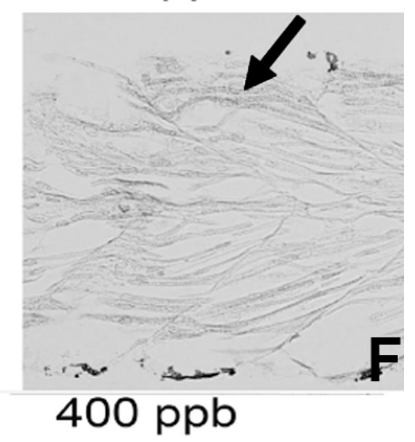

Fig. 3. Photographs of 5 $\mu \mathrm{m}$ thick paraffin section of zebrafish embryos that were stained with eosin. control and $\mathrm{Hg}$ cl treated zebrafish embryos. Arrows indicate muscle fibers. A and $\mathrm{D}$ are taken of a control embryo; photographs $B$ and $E$ are from an embryo exposed to $200 \mathrm{ppb}$ mercuric chloride. $\mathrm{C}$ and $\mathrm{F}$ are from an embryo exposed to $400 \mathrm{ppb}$ mercuric chloride. The boxes in photographs A-C are enlarged in photograph s D-F, respectively. 


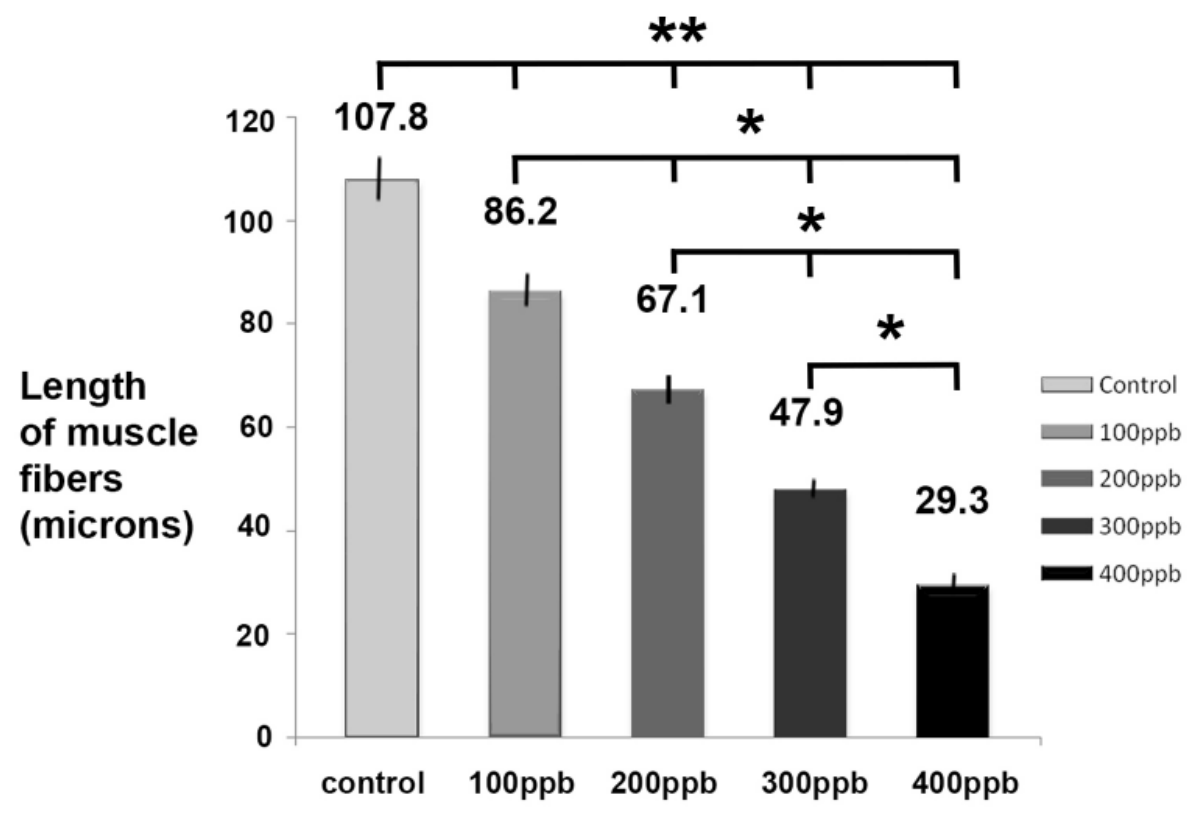

Fig. 4. Graph showing decreases in the muscle fiber length in the treated embryos compared to control embryos. The calculated average muscle fiber length for each group is listed above each bar. Error bars $=$ SEM; $*=p<0.05 ; * *=p<0.01$

\section{Effect of $\mathrm{HgCl}$ on muscle fiber degeneration}

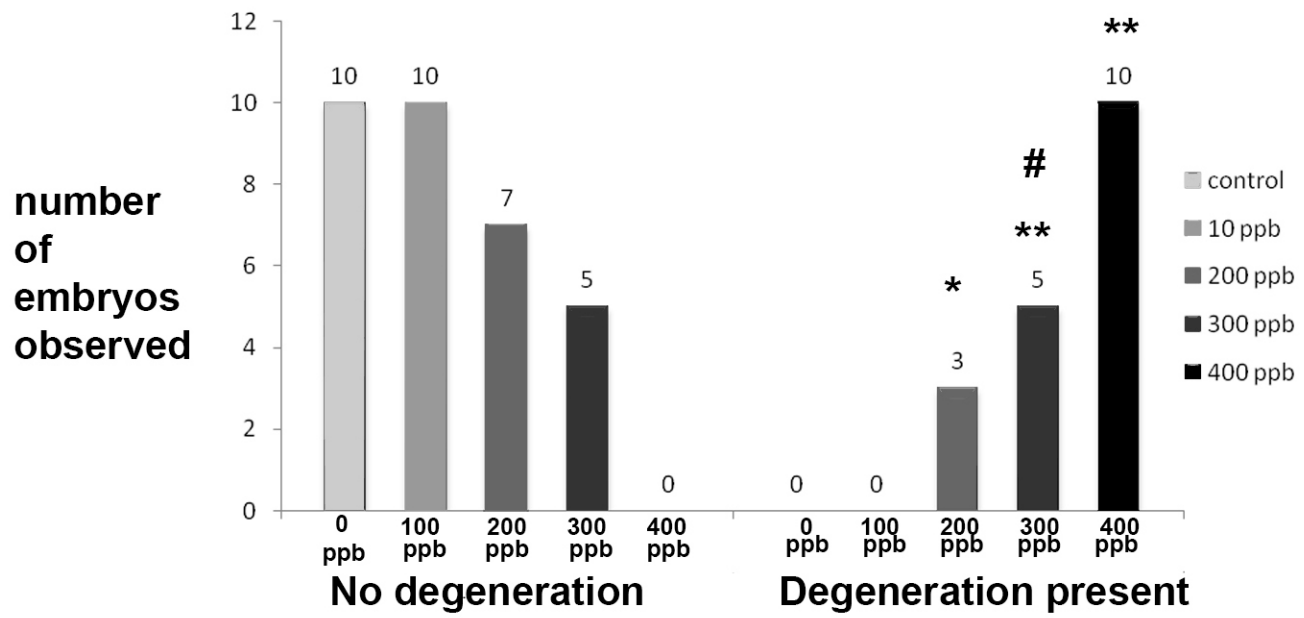

Fig. 5. Graph indicating numbers of zebrafish embryos in each group that did or did not show degeneration of muscle fibers. $\mathrm{N}=10$ for each group. Data analyzed using Chi-square analysis. $*=\mathrm{p}<0.05 ; * *=\mathrm{p}<0.01$; $\#=\mathrm{p}<0.01$

We then assessed whether muscle fiber degeneration was observed in embryos from each exposure group, using the Chi-square test to compare control embryos to embryos exposed to the different concentrations of mercuric chloride (Fig. 5). Embryos exposed to $200 \mathrm{ppb}$ and higher concentrations of mercuric chloride all showed increased muscle fiber degeneration compared to muscle fibers observed in control embryos (200 ppb, $\mathrm{p}=0.03 ; 300 \mathrm{ppb}, \mathrm{p}<0.0001$ and $400 \mathrm{ppb}, \mathrm{p}<0.0001)$. Also, a dose response was observed when the two highest mercuric chloride exposure concentrations were compared $(\mathrm{p}=0.01)$. 

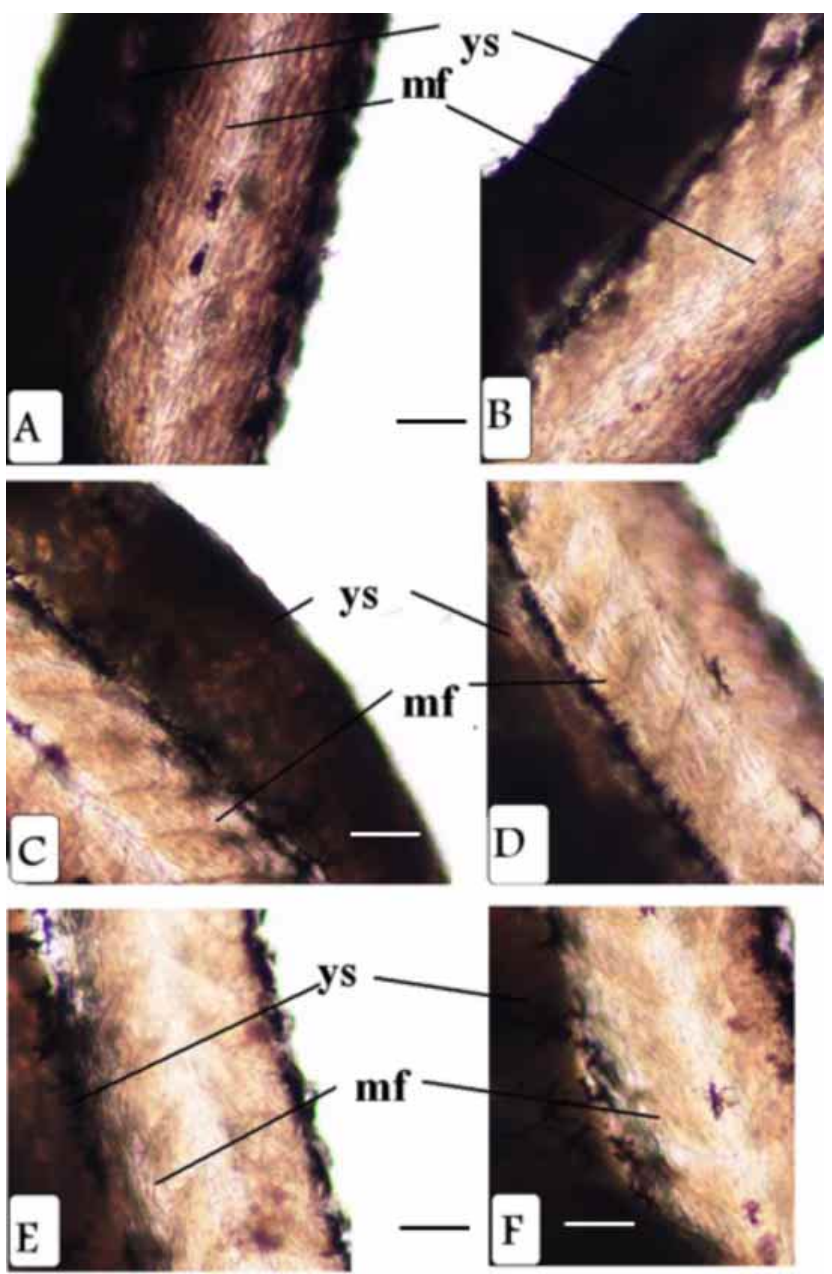

Fig. 6. Photographs of whole mount zebrafish that were stained using immunohistochemistry with anti-myosin antibody. Photographs; $\mathrm{A}=$ Control, $\mathrm{B}=100$ ppb mercuric chloride, $\mathrm{C}=200$ ppb mercuric chloride, $\mathrm{D}=300 \mathrm{ppb}$ mercuric chloride, $\mathrm{E}$ and $\mathrm{F}=$ $400 \mathrm{ppb}$ mercuric chloride. $\mathrm{ys}=$ yolk sac, $\mathrm{mf}=$ stained myosin in the muscle fibers. Scale bar $=125 \mu \mathrm{m}$ in each photograph.
We observed that all embryos exposed to mercuric chloride showed little to no positive immunohistochemical staining for myosin (Fig. 6). Also, treated embryos revealed abnormal muscle fiber shapes, specifically twisting of the muscle fibers of the treated embryos (Fig. 4) as well as the occurrence of irregular muscle fiber diameters along the fiber length. Control embryos and embryos exposed to $100 \mathrm{ppb}$ or $200 \mathrm{ppb}$ mercuric chloride showed no significantly twisting of the skeletal muscle fibers. Embryos exposed to $300 \mathrm{ppb}$ and $400 \mathrm{ppb}$ mercuric chloride demonstrated a large increase in twisted muscle fibers (Fig. 7); ( $<0.01$ and $\mathrm{p}$ $<0.001$, respectively).

\section{DISCUSSION}

At $6 \mathrm{~h}$ post fertilization, zebrafish embryos were exposed for $42 \mathrm{~h}$ to one of five concentrations ( 0 [negative control], 100, 200, 300, and 400 ppb of mercuric chloride) and a range of muscle abnormalities was observed in mercury-exposed embryos. Blood levels of mercury in the human population ranges from $0.6 \mu \mathrm{g} / \mathrm{L}$ (or ppb) up to 20 $\mu \mathrm{g} / \mathrm{L}$, with toxic symptoms occurring at 100 to $200 \mu \mathrm{g} / \mathrm{L}$ blood levels in humans (Ye et al., 2016). These reports indicate that the concentrations of mercury used in this study are relevant to the range of environmental, human exposures to mercury.

While many studies have examined how mercury exposure affects the developing brain, less is known about the effects of mercury on other developing organ systems, including developing skeletal muscle. Most human mercury exposure is due to methylmercury contamination of food. However, inorganic forms of mercury such as mercuric

\section{Effect of $\mathrm{HgCl}$ on muscle fiber morphology}

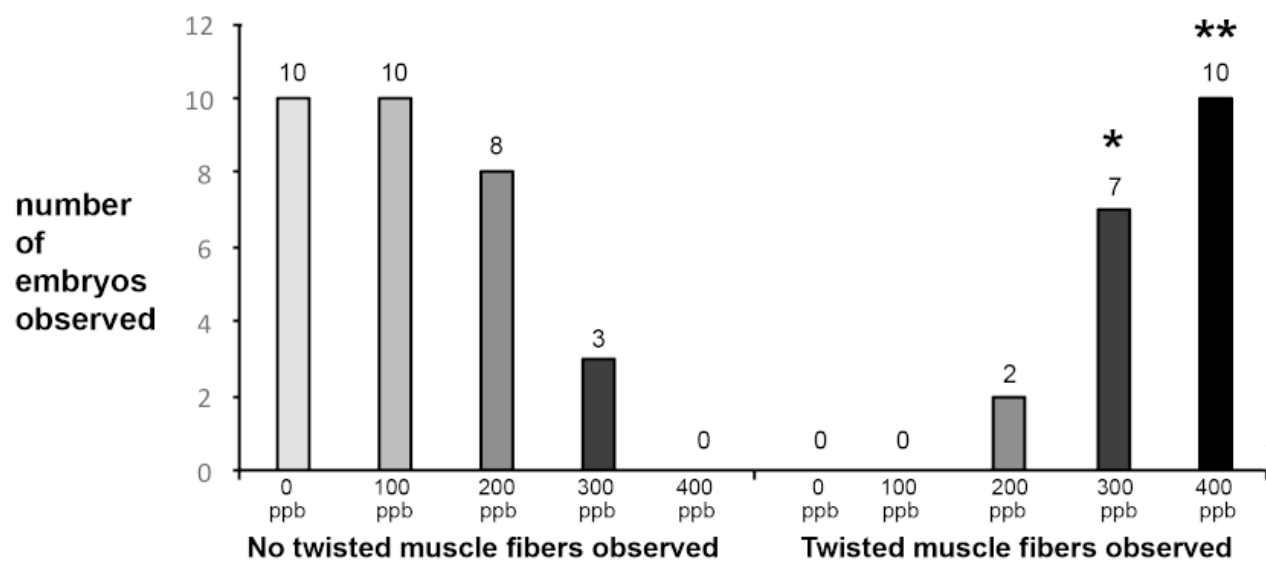

Fig. 7. Graph indicating numbers of zebrafish embryos in each group that did or did not show twisted muscle fibers. $\mathrm{N}=10$ for each group. Data analyzed using Chi-square analysis. * $=\mathrm{p}<0.05 ; * *=\mathrm{p}<0.01$ 
chloride also occur in our environment, especially with occupational exposures to mercury, and conversion of methylmercury to inorganic mercury over long periods of time also occurs (Ye et al.). It is thought that the ratio of inorganic mercury to organic mercury increases with age due in part to the limited ability of inorganic mercury to cell membranes compared to organic forms of mercury (Ye et $a l$.). In fish, mercury accumulates in many organs, but muscle is the primary repository for mercury (Liu et al.).

In this study, zebrafish embryos were assessed at $48 \mathrm{~h}$ post fertilization for morphological deformities in developing skeletal muscle in the trunk and tail after exposure to mercuric chloride. Decreased myosin expression, as demonstrated by IHC staining, suggested that altered muscle protein conformation may have occurred, which is consistent with effects of methylmercury on muscle development in zebrafish embryos (Liu et al.). Abnormalities in the expression of different myosin forms during development have been associated with congenital defects in mammals including joint contractures and orofacial dysmorphisms (Schiaffino et al., 2015). Exposure to trace elements, including mercury has been associated with cardiac muscle dysfunction presumably through adverse effects on mitochondrial function and muscle cell metabolism (Frustaci et al., 1999). We also observed significant shortening and increased twisting of skeletal muscle fibers in a dose-dependent manner due to exposure to increasing concentrations of mercuric chloride. These morphologic abnormalities suggest that myofibrils may be undergoing degeneration. In a research model looking at skeletal muscle development in chick embryos, exposure to decamethonium bromide resulted in muscle degeneration characterized by reduced or missing myofibrils as well as significantly decreased myosin protein expression (Macharia et al., 2004). Decreased staining of myosin in myofibrils also may be due to a slower or delayed rate of myosin development. Mercury ions have high affinity to bind to sulfhydryl ( $\mathrm{SH}$ ) groups, which are found in the sulfur-containing amino acids, cysteine, and methionine. Glutathione has been shown to be protective against mercury toxicity, in support that SH groups are possible sites of action for mercury toxicity (Musiek \& Hanlon). Thus, it is conceivable that mercury adversely acts on myosin molecules through binding to $\mathrm{SH}$ groups (Musiek \& Hanlon).

We know that exposure to mercury reduces myosin ATPase activity, which can be associated with changes in shape and activity of myosin filaments (Lin \& Lim, 1993). The altered muscle fiber shapes observed in treated embryos in this study could be due to effects of mercuric chloride on the contraction mechanism of muscle fibers mercury exposure of skeletal muscle can decrease the activity of myosin ATPase, which catalyzes ATP breakdown into ADP (Vassallo et al., 1999). Reduced ATPase activity could lead to abnormal muscle development and function. Mercury also has been shown to inhibit sarcolemmal $\mathrm{Na}+\mathrm{K}+$-ATPase as well as sarcoplasmic reticulum Ca2+-ATPase activity (Hechtenberg \& Beyersmann, 1991). Altering these ion pumps can result in calcium overload, triggering calcium release from the sarcoplasmic reticulum (Hechtenberg \& Beyersmann), leading to increased muscle fiber tension and shortened muscle fiber lengths, which also are consistent with observations noted in this study.

Liu et al. reported that exposure to methylmercury resulted in changes in several genes associated with muscle development, including postna, atp2a1 and mylpfa and that dysregulation of genes by exposure to mercury disrupts muscular development. Postna is a gene that is involved in muscle cell differentiation (Liu et al.). The atp2a1 gene encodes a calcium pump, which is essential for normal muscle function (Liu et al). Myosin light chains, which are encoded by mylfa, also are essential for normal muscle function (Liu et al.). While we did not examine gene expression in this study, we speculate that direct exposure to mercury is likely to alter gene expression in developing skeletal muscle.

In conclusion, the treated zebrafish embryos in this study showed an apparent decrease in development in a dosedependent manner with exposure to mercuric chloride, supporting the potent toxicity of inorganic mercury. Mercury has the potential to disrupt nearly every cell function, including membrane transport, volume regulation, microtubule formation, protein and RNA synthesis and signal transduction (Aduayom et al., 2005). Also, skeletal muscle fibers in treated embryos appeared to exhibit aspects of degeneration that could be due to mercury's interference with cell membrane transport or $\mathrm{Ca}^{2+}$ metabolism (Hare \& Atchison, 1992). Future studies should focus on discerning how much skeletal muscle fiber alteration is due to developmental disruption and how much is due to muscle fiber degeneration and assessment of the effects of early exposure to mercury on developing muscle cell gene expression also would be an important study to carry out in this model system.

\section{ACKNOWLEDGEMENTS}

Partial support for this study was provided through a Distinguished Scholar Award to Dr. Eid Moussa from the Arab Fund Fellowship Program. 
MOUSSA, E. A.; FAROUK, S. M.; ABBOTT, L. C. \& HASSAN, S. Uso de embriones de pez cebra (Danio rerio) como modelo para evaluar los efectos del mercurio en el desarrollo del músculo esquelético: Un estudio morfométrico e inmunohistoquímico. Int. J. Morphol., 36(3):901-908, 2018.

RESUMEN: La exposición al mercurio en el medio ambiente sigue siendo una preocupación mundial importante, especialmente para el desarrollo de embriones y fetos. Si bien un amplio esfuerzo de investigación se ha centrado en los efectos del mercurio en el sistema nervioso en desarrollo, se sabe mucho menos sobre los efectos adversos en otros sistemas orgánicos, incluido el desarrollo del músculo esquelético. Expusimos embriones de pez cebra en desarrollo a un rango de concentraciones de cloruro de mercurio (100 a $400 \mathrm{mg} / 1$ o ppb) y los comparamos con embriones de control $(0 \mathrm{mg} / \mathrm{L}$ de cloruro de mercurio). Los embriones se examinaron a las 48 horas después de la fertilización (HPF) pararealizar la morfometría y verificar las deformidades morfológicas de las fibras del músculo esquelético en el tronco y la cola. Los embriones expuestos a $400 \mathrm{ppb}$ de cloruro de mercurio mostraron una disminución de las áreas del tronco y la cola en comparación con los embriones de control. Se observó una reducción dependiente de la dosis en la longitud de la fibra muscular, y la exposición a todas las concentraciones de cloruro de mercurio utilizadas en este estudio, dio como resultado una tinción inmunohistoquímica de fibra muscular disminuida con anticuerpos anti-miosina. Se observaron diámetros irregulares de fibras musculares, fibras musculares retorcidas y fibras musculares degeneradas en secciones de embriones teñidos con eosina en las concentraciones de exposición más altas. La evidencia presentada en este estudio sugiere que la exposición incluso a bajas concentraciones de cloruro mercúrico afecta negativamente el desarrollo de la fibra del músculo esquelético o la integridad de la fibra muscular, o ambas.

PALABRAS CLAVE: Pez cebra; Desarrollo de fibra muscular; Músculo estriado; Miosina; Desarrollo embriónico.

\section{REFERENCES}

Aduayom, I.; Denizeau, F. \& Jumarie, C. Multiple effects of mercury on cell volume regulation, plasma membrane permeability, and thiol content in the human intestinal cell line Caco-2. Cell Biol. Toxicol., 21(3-4):163-79, 2005.

Chan, M. C.; Bautista, E.; Alvarado-Cruz, I.; Quintanilla-Vega, B. \& Segovia, J. Inorganic mercury prevents the differentiation of SH-SY5Y cells: Amyloid precursor protein, microtubule associated proteins and ROS as potential targets. J. Trace Elem. Med. Biol., 41:119-28, 2017.

Clark, J. D.; Gebhart, G. F.; Gonder, J. C.; Keeling, M. E. \& Kohn, D. F. Special Report: The 1996 Guide for the Care and Use of Laboratory Animals. ILAR J., 38(1):41-8, 1997.

Follo, C.; Ozzano, M.; Montalenti, C.; Santoro, M. M. \& Isidoro, C. Knockdown of cathepsin $\mathrm{D}$ in zebrafish fertilized eggs determines congenital myopathy. Biosci. Rep., 33(2):e00034, 2013.

Frustaci, A.; Magnavita, N.; Chimenti, C.; Caldarulo, M.; Sabbioni, E.; Pietra, R.; Cellini, C.; Possati, G. F. \& Maseri, A. Marked elevation of myocardial trace elements in idiopathic dilated cardiomyopathy compared with secondary cardiac dysfunction. J. Am. Coll. Cardiol., 33(6):1578-83, 1999.

Gentès, S.; Maury-Brachet, R.; Feng, C.; Pedrero, Z.; Tessier, E.; Legeay, A.; Mesmer-Dudons, N.; Baoudrimont, M.; Maurice, L.; Amouroux, D. \& Gonzalez, P. Specific effects of dietary methylmercury and inorganic mercury in zebrafish (Danio rerio) determined by genetic, histological, and metallothionein responses. Environ. Sci. Technol., 49(24):14560-9, 2015.

Hare, M. F. \& Atchison, W. D. Comparative action of methylmercury and divalent inorganic mercury on nerve terminal and intraterminal mitochondrial membrane potentials. J. Pharmacol. Exp. Ther., 261(1):166-72, 1992.

Hassan, S. A.; Moussa, E. A. \& Abbott, L. C. The effect of methylmercury exposure on early central nervous system development in the zebrafish (Danio rerio) embryo. J. Appl. Toxicol., 32(9):707-13, 2012.

Hechtenberg, S. \& Beyersmann, D. Inhibition of sarcoplasmic reticulum Ca(2+)ATPase activity by cadmium, lead and mercury. Enzyme, 45(3):109-15, 1991.

Incardona, J. P.; Collier, T. K. \& Scholz, N. L. Defects in cardiac function precede morphological abnormalities in fish embryos exposed to polycyclic aromatic hydrocarbons. Toxicol. Appl. Pharmacol., 196(2):191-205, 2004.

Li, D.; Lou, Q.; Zhai, G.; Peng, X.; Cheng, X.; Dai, X.; Zhuo, Z.; Shang, G.; Jin, X.; Chen, X.; Han, D.; He, J. \& Yin, Z. Hyperplasia and cellularity changes in IGF-1-overexpressing skeletal muscle of crucian carp. Endocrinology, 155(6):2199-212, 2014

Lin, J. L. \& Lim, P. S. Massive oral ingestion of elemental mercury. J. Toxicol. Clin. Toxicol., 31(3):487-92, 1993.

Liu, Q.; Klingler, R. H.; Wimpee, B.; Dellinger, M.; King-Heiden, T.; Grzybowski, J.; Gerstenberger, S. L.; Weber, D. N. \& Carvan, M. J. 3rd. Maternal methylmercury from a wild-caught walleye diet induces developmental abnormalities in zebrafish. Reprod. Toxicol., 65:272-82, 2016.

Macharia, R.; Patel, K.; Otto, W. R.; McKinnell, I. W. \& Christ, B. Decamethonium bromide-mediated inhibition of embryonic muscle development. Anat. Embryol. (Berl.), 208(1):75-85, 2004.

Musiek, F. E. \& Hanlon, D. P. Neuroaudiological effects in a case of fatal dimethylmercury poisoning. Ear Hear, 20(3):271-5, 1999.

Reis, M. F.; Sampaio, C.; Brantes, A.; Aniceto, P.; Melim, M.; Cardoso, L.; Gabriel, C.; Simão, F. \& Miguel, J. P. Human exposure to heavy metals in the vicinity of Portuguese solid waste incinerators--Part 1: biomonitoring of $\mathrm{Pb}, \mathrm{Cd}$ and $\mathrm{Hg}$ in blood of the general population. Int. J. Hyg. Environ. Health, 210(34):439-46, 2007.

Schiaffino, S.; Rossi, A. C.; Smerdu, V.; Leinwand, L. A. \& Reggiani, C. Developmental myosins: expression patterns and functional significance. Skelet. Muscle, 5:22, 2015.

Scholz, S.; Fischer, S.; Gündel, U.; Küster E.; Luckenbach, T. \& Voelker, D. The zebrafish embryo model in environmental risk assessment--applications beyond acute toxicity testing. Environ. Sci. Pollut. Res. Int., 15(5):394-404, 2008.

Swaddle, J. P.; Diehl, T. R.; Taylor, C. E.; Fanaee, A. S.; Benson, J. L.; Huckstep, B. N. \& Cristol, D. A. Exposure to dietary mercury alters cognition and behavior of zebra finches. Curr. Zool., 63(2):213-9, 2017.

Uchikawa, T.; Kanno, T.; Maruyama, I.; Mori, N.; Yasutake, A.; Ishii, Y. \& Yamada, H. Demethylat Demethylation of methylmercury and the enhanced production of formaldehyde in mouse liver. J. Toxicol. Sci., 41(4):479-87, 2016.

Vassallo, D. V.; Moreira, C. M.; Oliveira, E. M.; Bertollo, D. M. \& Veloso, T. C. Effects of mercury on the isolated heart muscle are prevented by DTT and cysteine. Toxicol. Appl. Pharmacol., 156(2):113-8, 1999.

Westerfield, M. The Zebrafish Book. A Guide for the Laboratory Use of Zebrafish (Danio rerio). $4^{\text {th }}$ ed. Eugene, University of Oregon Press, 2000.

Ye, B. J.; Kim, B. G.; Jeon, M. J.; Kim, S. Y.; Kim, H. C.; Jang, T. W.; Chae, H. J.; Choi, W. J.; Ha, M. N. \& Hong, Y. S. Evaluation of mercury exposure level, clinical diagnosis and treatment for mercury intoxication. Ann. Occup. Environ. Med., 28:5, 2016.

Yin, H.; Price, F. \& Rudnicki, M. A. Satellite cells and the muscle stem cell niche. Physiol. Rev., 93(1):23-67, 2013.

Zhen, H.; Wen, M.; Yang, Y.; Can, Z.; Hui, G.; Li, X. \& Deli, L. Toxic effects of $\mathrm{HgCl} 2$ on activities of SOD, AchE and relative expression of SOD, AChE, CYP1A1 of zebrafish. Ecotoxicology, 23(10):1842-5, 2014.

\section{Corresponding Author:}

Dr. Said Hassan

Department of Anatomy and Embryology

Faculty of Veterinary Medicine

Suez Canal University

Ismailia 41522

EGYPT

Received: 12-01-2018

Accepted: 12-04-2018

Email: shassan1978@gmail.com 